【土木計画学研究・論文集 No. 3 1986年 1 月 招待論文】

\title{
非集計行動モデルとその実用性* \\ Disaggregate Behavioral Model and Its Practicability
}

屋 井 鉄 雄 ${ }^{* *}$

By Tetsuo Yai

は じめに

非集計行動モデルが新しい交通需要予測モデルと して広く受け入れられ, 開発当初より数多くの研究 が積み重ねられるに至った背景には，近年の交通計 画自体の多様化と従来の需要予測方法による対応の 限界と言った問題に加え，交通行動の解明に対して 効用理論の発展に伴うより科学的な接近が可能とな った点を挙げられる.

確率効用理論という経済学上の確固たる基盤を有 し，個々人の選択行動を直接反映しうる有効な手法 であるという点が注目され，次のような利点が強調 された. すなわち，モデル構築には少ないサンプル で斉み, 数多くの政策変数を導入でき, その結果, 予測作業の軽減ときめ細かな政策評価への対応が実 現できるといった点である.このような認識のもと で, 開発当時は従来の四段階推定法の総ての段階を 非集計行動モデルで置き替えることによって，より 精度の高い予測が行えると考えられた.

しかし，その後の研究により，かならずしも総て に適用可能とは言えないことが明らかとなった．機 関分担への適用性の高さは多くの研究で確認されて

* キーワード：交通需要予測, 非集計行動モデル

**正会員 工博 京都大学助手 工学部土木工学科 ( ( $606 /$ 京都市左京区吉田本町)
いるが，発生や分布段階については，それを疑問視 する意見も多い. 実際, 良好なモデルが得られたと の報告は見当たらず，開発当初に想定された，四段 階推定法と同等な適用方法を志向する研究も鳴りを 潜めた状況にある. 従来の集計型モデルでは十分な 対応が期待できない様々な対象や，きめ細かな政策 等への適用は，交通手段選択を中心に依然として進 められ，大きな成果を得て抢り，そのような場面で の有効性は広く認められてきたと言えよう。しかし， 先に述べた発生，分布段階での不十分さは，非集計 行動モデルによる総合的な交通需要予測を実現する 上での最大の問題となっている.

また，非集計行動モデルの理論的長所と言える， 個々人の行動の反映という点についても, 否定的な 見解が一部で示され，特に非集計化することと行動 を表現するということを同義に用いた，開発当初の 用語の混同が指摘されている.

これらの示唆するところは, 非集計行動モデルを 適切な対象に的確な方法で適用することの必要性で あり，また無条件に総て良しと楽観的に見なした開 発当時に対する幾許かの反省でもある. このような 現実的視点に立って研究を進める動きは，研究開始 時期の若干遅れた我が国にあっては，当初より少な からず認められ, 特に近年の非集計行動モデルワー 
クショップ及びその総括としての講習会の開催にそ れらの成果が見られる.

ただし，我が国の場合，実用化を急ぐ傾向が強く， そのための研究が先行し, 先に述べた行動的か否か といった基礎的課題の検討は根付いてはいない状況 にあった. しかし，振り返って非集計行動モデルが 開発当初に授けられた, 様々な方法論上の利点を真 に満たすモデル方法論を, 開発・実用化することの 意義は計り知れず, 近年認識されている限定された 非集計行動モデルに留まることなく, 開発研究を進 め, 実用化と基礎的モデル開発との両者を成立させ た研究の進展が望まれる.

本研究では, このような考えに立ち, 今後の研究 方向に対して 1 つの指針を与えることを最終的な目 標に揭げ，行動モデルと称される様々なモデルの体 系的な整理と, 実用化のための研究の現状とを示し た上で，非集計行動モデルにより総合的な需要予測 を可能とするために必要な，分布交通量推計に対す る新たな方法論の提案を行う.

すなわち，1.において非集計行動モデルの概要 を説明した後，2. で非集計行動モデルを広義にと らえた上で，モデルの体系的整理を試み，3.におい て㬰用化のための研究の現状を概括する. そして,

4.に拉いて，非集計行動モデルを用いて分布交通 量を推計するための, 新たな方法論を提案する.

\section{1. 非集計行動モデルの概要}

非集計行動モデルの理論的基盤が確率効用理論に あることは既に述べたが，これは以下のように説明 できる.

すなわち, トリップを行う個人 $(n)$ が, 効用の最 大となる選択肢を選ぶ ( 効用最大化行動) と考える. その際, 効用は確定的に決まらず, 確率変動すると 考える (確率効用) 。これは，同一の選択肢であっ ても，効用が変化しうることを意味しており，選択 行動自体が確率的に変動することとなる.

確率効用理論では, この効用 $\left(U_{i n}\right)$ を確定的に定 まる部分 ( 確定項 : $V_{\text {in }}$ ) と確率変動する部分 ( 確
率項 : $\left.\varepsilon_{i n}\right)$ との和で表わし,

$$
U_{i n}=V_{i n}+\varepsilon_{i n}
$$

と記述する. そして, (1-1) のもとで, 選択肢 $i$ を選ぶ確率 $\left(P_{\text {in }}\right)$ を,

$$
P_{i n}=\operatorname{Prob}\left[U_{i n} \geq U_{j n}, \quad \forall j \in C_{n}, \quad j \neq i\right]_{(1-2)}
$$

によって表現する. $C_{n}$ は個人 $n$ の選択肢集合である. 上式は，選択肢 $i$ の効用が他の総ての選択肢の効用 よりも大きな確率が， $i$ を選ぶ確率 ( 選択確率) で あることを意味する.

(1-2)において, $U_{i n}$ を構成する $\varepsilon_{i n}$ に適切な分 布を仮定した上で, 密度関数の積分計算を行えば, 非集計行動モデルの導出が行える. $\varepsilon_{i n}$ を選択肢相 互に独立なガンベル分布 (Gumbel Distribution)

$$
\operatorname{Prob}\left[\varepsilon_{i n} \leq \varepsilon\right]=e^{-e^{-\left(\varepsilon+\alpha_{i n}\right)} \cdots \cdots} \quad(1-3)
$$

とおけば，ロジットモデル(Logit Model)，

$$
P_{i n}=\frac{e^{V_{i n}-\alpha_{i n}}}{\sum_{j \in C_{n}} e^{V_{j n}-\alpha_{j n}}}
$$

が得られ，また正規分布とすればプロビットモデル (Probit Model) が得られる.

モデルのパラメータ推定に際しては， $\alpha_{i n}$ を個人 ごとには変わらない定数項と考えた上で， $V_{i n}$ を一 般に加法的効用関数で表わす.

$$
V_{i n}=\sum_{k} \theta_{k} X_{i n k}
$$

上式で, $\theta_{k}$ はパラメータ, $X_{i n k}$ は選択肢 $i$ の $k$ 番 目の特性を表わす. $\theta_{k}$ の推定は，最尤法を用いるこ とにより,

$$
\begin{gathered}
L=\sum_{n} \sum_{i \in C_{n}} \delta_{i n} \ln P\left(i \mid \boldsymbol{x}_{n}, \widehat{\boldsymbol{\theta}}\right) \cdots \cdots(1-6) \\
P\left(i \mid \boldsymbol{x}_{n}, \widehat{\boldsymbol{\theta}}\right)=P_{i n}
\end{gathered}
$$

なる対数尤度の最大化により行える. $(1-6)$ の $\delta_{i n}$ は選択実績を表わし， $i$ を選択しているときのみ 1 , 他では 0 となる.

しかし, 以上で求まるモデルは, 個々人の効用及 
び選択確率を表わすにすぎず，需要予測のためには 集計化して集団のシェアとする必要がある.ここで 母集団における特性値の分布 $f(\boldsymbol{X})$ が得られていれ ば,

$$
S_{i}=\int_{\boldsymbol{X}} P(i \mid \boldsymbol{X}, \hat{\boldsymbol{\theta}}) f(\boldsymbol{X}) d \boldsymbol{X} \cdots \cdots \cdots(1-7)
$$

によって集計シェア $S_{i}$ を求められるが, 一般に $f(\boldsymbol{X})$ が未知であるため, 何らかの近似計算が要求される. これが所謂集計問題と言われ，基本的には 5 種類の 対処方法 ( 簡便法, 分類法, 数え上げ法, 積分法, モーメント法）が提案されており1)，これにより集 計シェアの算出が行え, 需要予測が可能となる.

\section{2. 個人行動モデルの発展}

\section{（1）個人行動モデルの開発の経緯}

非集計行動モデルを前章に従って定義すれば, 確 率効用理論に基づき効用最大化行動を表現したもの となるが，本章ではこれをより広く捉え，ある種の 行動仮説に基づき個々人の離散的な選択を表現しう るものとする.このように広義に捉えたモデルを， 個人行動モデルと称し，ここで体系的な整理を試み る.

個々人の行動が効用の大小より定まると考えるこ と自体は合理的であるが，効用最大化の仮説におい て切り捨てられた様々な代替的行動仮説を内在する モデルもまた，現象を記述する上で有用である点は 論をまたない.このような視点に立つとき，個人行 動モデルの開発が，4つの大まかな流れで進められ てきたと解釈することが出来る. 第 1 は, MNL (Multinomial Logit) モデルから TEV ( Tree Extreme Value ) モデルに至る, 確率効用理論としての 展開が最も進んだ流れである，第 2 は，選択におけ る判断基準である効用に識閾 ( Threshold) が存在 すると仮定し，これを明示的に取り込んだモデル開 発の流れである. 第 3 は, 選択肢の集合自体を決定 する過程を行動モデルに内包したものであり，第 4 は, EBA ( Elimination By Aspects ) モデルより派
生した辞書的 ( Lexicographic) 選択モデルのように, 選択要因の同時的評価を前提としないモデル開発の 流れである.これらに含まれない行動モデルをも対 象に，筆者の知る範囲で開発経緯を図示したものが, 図ー1である. 以下，順を追って概要を示す.

(1) 第 1 の流れは Mc Fadden $\left.{ }^{2}\right) に$ 始まり, 非集計 行動モデルの原形はここで確立された. Mc Fadden は確率効用理論より, MNL モデルと MNP (Multinomial Probit) モデルとの 2 種類を導出したが, もっぱら適用上の簡便さより前者が着目され, その 後のモデル開発に係わる研究は, 前者の有する IIA 特性 ( 無関係選択肢からの独立特性) に対処する方 向で進んだ. これは, モデルが IIA 特性を満たす場 合に, 類似性の強い選択肢が部分的に含まれる状況 ( 所謂, 赤バスー青バス問題) を, 的確に表現し得 ないためであり，例えば Mclynn ${ }^{3)}$ は MNL モデル の選択確率を，総ての選択肢の確率によって修正す る FC ( Fully Competitive) モデルを提案し,この 問題に対処しようと試みた. しかし，修正の根拠を 行動仮説に求められず, 確率効用理論とも斉合する ものでは無かった.

一方, Ben-Akiva ${ }^{4)}$ は目的地と交通手段との選択 を段階的に表現する際，周辺確率に現われるログサ ム ( LOGSUM ) 変数に係数を乗ずるモデルを示した. 係数の值により, 同時選択と段階選択との両者を表 現しうることが明らかとされたが, 係数の持つ効用 理論上の意味については, 次の NL ( Nested Logit) モデルの開発を待つこととなった.

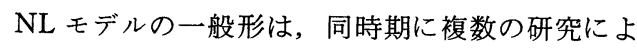
って, 確率効用理論との関連で明らかとされている. $\mathrm{NL}$ モデルは，目的地と交通手段といった多次元の 選択に限らず, 同一種内の選択肢相互の類似性をも ッリー構造として表現できる点に特色があり, その 結果 IIA 特性の問題を理論的に解消することに成功 した. Daly · Zachary ${ }^{5)}$ は確率効用理論との斉合に 必要な 5 つの条件を示し, NL モデルが総てを満た すことを明らかにした，また，Williams $\left.{ }^{6}\right)$ は確率効 用理論より，NL モデルとそれを更に一般化した 


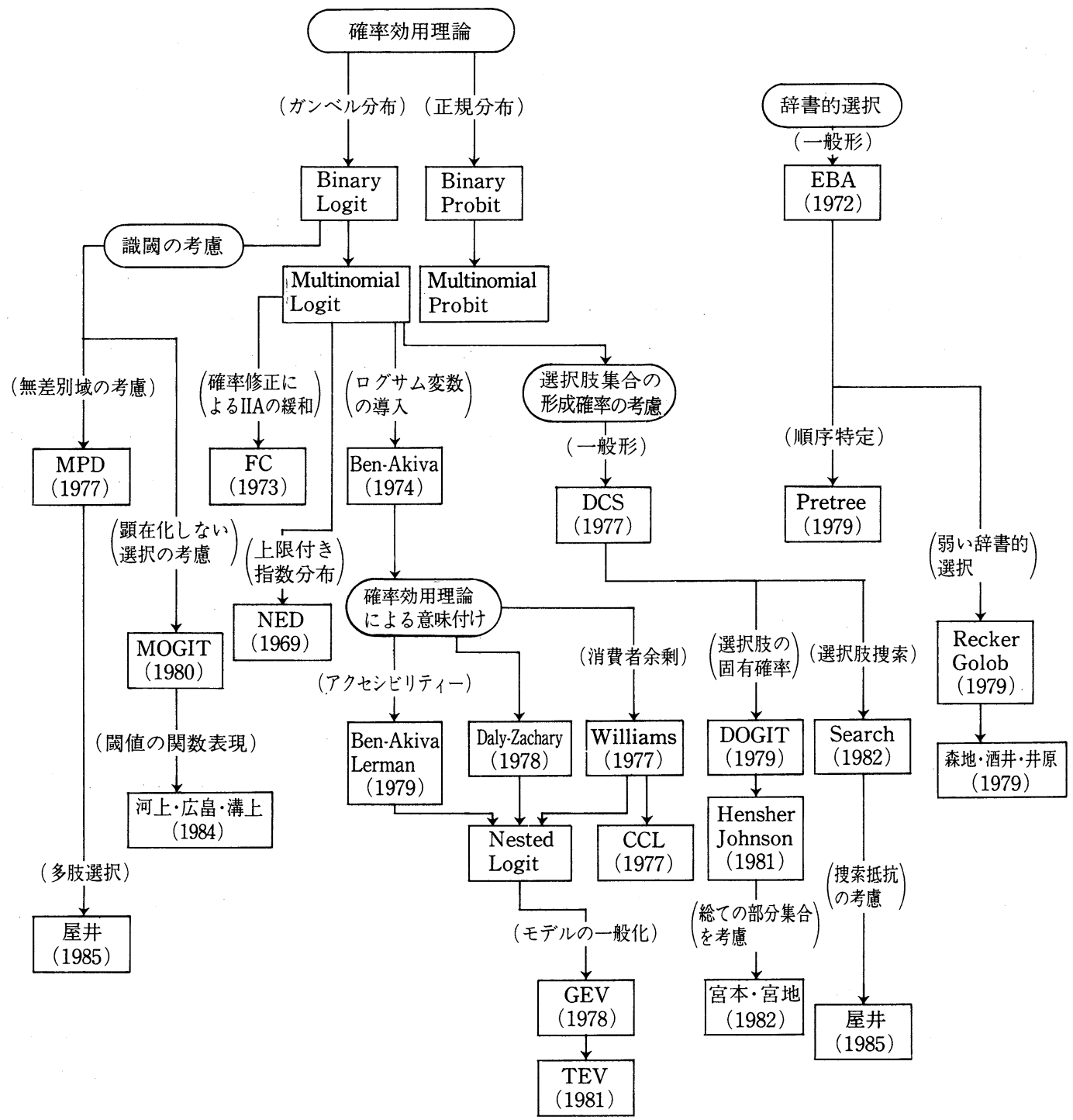

\section{図-1 個人行動モデルの開発経緯}

CCL ( Cross Correlated Logit) モデルを提案した. $\mathrm{CCL}$ モデルは 2 次元の選択を NL モデルで表現する 際の 2 通りのッリ一構造を, 同時に表現しうるもの である，更に，Ben-Akiva・Lerman ${ }^{7)}$ は最大効用の 期待值で表わされるアクセシビリティーを MNL モ デルに導入する形式より，NLモデルを示している. 一方, Mc Fadden ${ }^{8}$ ) は確率効用理論と斉合するモデ ルの一般形の例を示し, GEV ( Generalized Extreme
Value ）モデルと称した.これより導出されるモデ ルには，MNL モデル，NL モデルが含まれる．また， Mc Fadden ${ }^{9}$ ) は NL モデルをより一般化し，任意のツ リー構造を表現可能な TEV (Tree Extreme Value) モデルを開発した. TEV モデルも GEV モデルに含 まれ，確率効用理論と斉合する.

以上は MNL モデルを出発点とし, 特に IIA 特性 に着目して, その問題解決を最大の動機に開発され 
たモデルであり，FCモデルを除き総て確率効用理 論と斉合する.

(2) 第 2 のモデル開発の流れは, 効用に識閾が存 在すると考えることによって，選択が無差別となる 状況や選択が顕在しない場合等を表現しようとする ものである.

例えば，住み替え行動や新交通への転換行動に対 し，効用の増加がある閾値を越える場合にだけ，選 択が顕在化すると考光，BL (Binary Logit) モデル によって表現した例がある10),11).この場合には，闇 值を定数項として処理しているため, 明示的に考慮 したとは言えないが，効用最大化行動で前提とする 個人の完全なる識別可能性を，二肢選択に限って緩

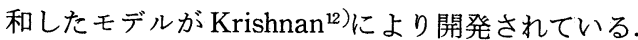

Krishnan は BL モデルをもとに，選択肢間の効用 差が閾値以下の場合には，無差別選択になると考え， その確率をも明示的に扱らことによって新たなモデ ルを開発し，MPD (Minimum Perceivable Difference）モデルと称した. MPD モデルでは, 効用項に 含まれる定数項とは別に閾値自体をも推定でき，確 率効用理論とも斉合する。

一方, 加藤・森杉・阿佐 ${ }^{13)}$ は, 効用の值が総ての 選択肢において負の場合には，選択が顕在化しない と考え，その確率をガンベル分布の仮定のもとで導 出している，そして，顕在化する確率と MNL モデ ルより定まる確率との積によって選択確率を表現し， そのモデルをMOGIT モデルと称した. これは効用 の閾値をゼロに固定したものと言え，確率効用理論 とは斉合しないが，選択が顕在化しない場合を明示 的に考慮している点に大きな意義がある。

また，河上・広畠・溝上 $\left.{ }^{10}\right)$ は，先に述べた転換行 動を表わすために，閾値を定数項として扱う方法に 加え，それがサービス変化以前の効用の関数になる と仮定して，BL モデルを修正している.

更に，屋井主1）はMPD モデル等で表わされる無 差別選択の状況を多肢選択において表現しうるモデ ルを提案している. そこでは，効用の最大值ですら
閾値を越えないような場合には，選択が無差別にな ると考え，その確率を導出した上で MNL モデルを 基に新たなモデルを示している.

以上のモデルは，識閾の存在という新たな仮説を 採用しており，導出されたモデルにおける確率効用 理論との斉合性の有無は大きな問題とならない.

(3) 第 3 の流れは, 選択肢集合そのものに着目し て，それが形成される確率を考慮した上で，選択確 率を導出しようとするものである. Manski ${ }^{14)}$ は総 ての部分集合の組合せを対象に，それらが形成され る確率と，集合が定まった条件下で選択肢を選ぶ確 率との積によって表わされる同時確率を，総ての部 分集合で加算することにより，全集合からの選択を 表現できる点に着目した．この一般形は DCS (Distributed Choice Set）モデルと称されるが，具体的 に定式化した例は少ない，Gaudry·Dagenais ${ }^{15}$ の提 案した DOGIT モデルは，部分集合のうち，全集合 と要素数が 1 つの集合との両者以外の形成される確 率をゼ口に固定したものであり，効用の大小によら ない選択肢に固有な確率をも同時的に考慮できる点 に特色がある.これに対し, Hensher · Johnson ${ }^{16)}$ は 選択肢集合の形成される確率も，効用の関数になる と考えて，DOGIT モデルを修正している．また宮 本・宮地 ${ }^{17)}$ は，選択肢集合の形成される確率の設定 において，各選択肢が集合に含まれる確率が，他の 選択肢と独立に定まると考え，総ての部分集合を対 象とするDCS モデルを定式化している.

以上が DCS モデルの具体例であるが，Richardson ${ }^{18)}$ は集合の形成と選択とを分離せずに，選択肢 を順番に捜索して行くモデルの開発を試みている. 新たに選択肢を捜索した結果得られる効用の期待値 と，捜索にかかわる費用とを比べ，後者が勝った時 点で捜索が打ち切られ，それまでに得た選択肢集合 のうち，効用の最大なる選択肢が選ばれると考える もので, サーチモデル ( Search Model) と称した. 選択が決定する時点で，始めて選択肢集合が定まる 構造となっており，形式上シミュレーションモデル 
の一種と言える. 実用上の問題は数多く残されてい るが，選択に至る過程を動的に捉えている点に大き な特色がある.

一方，屋井注 2 ) はサーチモデルで考慮された選択 肢の捜索費用に着目し，選択肢を集合に含めること による最小効用の期待値低下を, 選択における抵抗 值と考え，これを費用と見なした上で，選択がそれ を効用から差し引いた値を評価して決まると考え， 新たなモデルを提案している.

以上のモデルも第 2 の流れと同様に, 狭義の非集 計行動モデルの前提である確率効用理論とは，一般 に斉合しない.

また, これらのモデルとは別に，利用可能な選択 肢の限定に係わる研究が進められている.もっぱら モデルの適用上の課題として検討されているが，例 えば Landau ${ }^{19)}$ ほかは Time Budget を考え, 各人の 行動パターンに照らして到達可能な選択肢に限定す る方法を, 目的地選択モデルを対象として提案して いる.

(4) 第 4 の流れは, 選択において複数の要因をか ならずしも同時に評価してはいないと考える立場か ら, Tversky ${ }^{20)}$ の EBA モデルを簡略化する方向で 進められた研究である. EBA モデルでは, 選択肢の 属性に着目して選択肢を順次消去して行き，そのプ ロセスをただ一つの選択肢が残るまで続けると考え る. 消去順序は複数存在するが, これを特定すれば ッリー構造を表現できる. 実際, Tversky·Sattath ${ }^{21)}$ は消去順位を特定することにより，EBA モデルを簡 略化したPretree (Preference Tree) モデルを提案し ている. Pretree モデルは先験的に与えた選好ツリ 一を表現できる点で, 先に示した TEV モデルと共 通点が多い.

また，Foerster ${ }^{22)}$ は EBA モデルに代表される辞

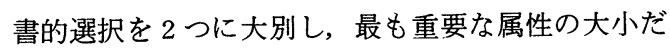
けで決まる強い辞書的選択と, 属性の重要度の順に 選択肢を評価して行き，属性の差が閾値を越えれば， その段階で選択が決まると考える弱い辞書的選択と
を示している. しかし，これらを具体化してモデル を提案した例は以外に少なく, Recker $\cdot \mathrm{Golob}^{23)}$ ， 森地・酒井・井原 ${ }^{24 ）}$ 等があるにすぎない，前者は選 択確率を用いずに，直接消去プロセスをモデル化し たものであり，後者は二肢選択に限定して弱い辞書 的選択行動を選択確率によって表現したものである. 間值を仮定する点で，第二の流れと共通するが，こ こでは要因の段階的な評価を表現するために用いて 掞り，モデルの考え方は異なる.

以上に述べた 4 つの流れとは別に，次のようなモ デルの開発も行われている. プロビットモデルは, Mc Fadden が MNL モデル同様，ランダム効用理論 より導出したという点では, 非集計行動モデルの基 本形の 1 つであるが，モデル自体は完成されたもの であり，もっぱら適用上の課題を解決するための研 究が進められている. しかし選択肢数の多い場合へ の適用上の困難さはさほど軽減されて扔らず，この 点が問題となり，近年のモデル開発が MNLモデル の改良を中心に進められてきたという経緯がある. また, Daganzo ${ }^{25}$ ) の NED ( Negative Exponential Distribution）モデルは, 効用のランダム項を上限付 きの指数分布で表わすことより導出されるが，上限 值により選択確率が大きく変化する性質を持つ. ま た, Sheffi ${ }^{26)}$ は自動車台数の選択のように, 序列化 された行動を，BL モデルの積で表現している.

\section{（2）モデルの適用性}

以上にまとめたように，近年の行動モデル開発の 多くは，MNL モデルの修正及び改良という点より なされてきたと言える. そのうち，IIA 特性に対処 した第 1 の流れ以外は, 確率効用理論の前提である 経済人の仮定自体を見直したものと考えることがで きる. 情報の不完全性や効用の不連続性, 選択肢や 要因の段階的評価，さらには習慣性や情報収集費用 といった,狭義の非集計行動モデルでは対応し得ない 行動仮説が，行動をより的確に表現し，また現象を より正確に把握する上で重要となる点は言うに及ば ない. しかし，近年の非集計行動モデルに関する研 
究は，実用化をめざす点に重心があったため，もっ ぱら MNLモデル，NLモデルといった理論面の明 快なモデルの適用を前提に進められてきた．モデル の性質が明らかな上に, 適用上の扱い易さが主な理 由と言えようが，この点については今一度考え直す 余地があろう.

すなわち，実用化を志向した非集計行動モデルと， 行動をより的確に表現するための個人行動モデルと を切り離して考え, 前者の観点では理論的根拠が明 らかで説得性の高いモデルを対象に, 主として実用 上の様々な課題が検討されることになるが，後者の 視点では, 様々な代替的行動仮説に基づくモデルの 基礎的検討が中心となる. NL モデルの開発におい て, Ben-Akiva ${ }^{4)}$ の提示した当初には, 確率効用理 論との斉合性が不明であった経緯もあり, 後の研究 で理論的精緻さが具わる例は少なくない，またモデ ルの適用上の扱い易さにしても, NL モデルが本来 同時推定を基本としながらも, MNL モデルと同等 な扱い易さを実現するために段階推定されている.

したがって, 同時推定を前提とする立場からは, NL モデルと他の様々なモデルとを区別し, 後者を特に 推定上の困難さより排除する必然性はあまりない。

以上を考慮するとき, 現段階では理論的根拠が不 十分であったり, 推定が複雑であるといった理由で モデルの開発及び適用を十分に行わないことは, 行 動の把握や現象の記述を適切に進めて行く上で好ま しくない. 実際の現象が如何なる原理に基づいて生 じるかを把握した上で，それに適合するモデルを選 択することが重要と言えるが，そのような現況再現 力の検証に留まらず, 将来の变化に対しモデルが如 何なる挙動を示すかを, 前以って大まかに把握して おくことが，特に需要予湘を前提とする際に要求さ れよう. 従来より開発されてきたモデルには，この 点をある程度把握しうるものも少なくない.

ただし, 近年開発されたモデルの多くは, 行動仮 説上の特定の問題に対処したものである.これをよ り一般化し, 個人・集団で変わりらる選択の原理を 十分に反映するモデルを開発する意義は大きい.

\section{3. 実用化のための研究の現状}

非集計行動モデルを需要予測方法として実用化す るための研究は, 様々な検討課題に対して行われて きたが，特にモデルの適用対象領域の把握を目的と するものが多く, 必要情報が整備されたとは言いが たい.しかし，断片的ながらも近年蓄積が進みつつ あり,この点を本章では項目を絞って整理する.

\section{（1）調查の方法と規模}

モデル構築のためのデータ収集方法には，家庭訪 問調查により過去の行動を抽出する方法と，トリッ プの途上で直接アンケートする方法との 2 つがある. 後者は選択肢別標本抽出法 (Choice-based Sampling $\left.^{27)}\right)$ と称され, 特に発生頻度の少ない行動を抽出 する場合等に有利な方法である. 一般に無作為標本 ではないが，この場合のモデルパラメータの推定問 題は理論的に解明されている28),29).

ただし, いずれの方法にせよ, 如何なる程度のサ ンプルがあれば推定上十分であるかという, 調査規 模縮小の可能性は, 非集計行動モデルの最大の利点 と言われながらも, 今だ一般性を有する結論を得て いない.これは, 対象とする地域や行動の種別によ るデータの違いや, モデルの選択肢数, 変数などに より必要サンプル数が变わる可能性があり, またサ ンプル数評価に用いる指標次第で, 十分とする根拠 が変わる点に原因があるためであり，一般化が困難 な課題の 1 つである.

しかし, 幾つかの実証的研究の成果を通して, 貴 重な情報が得られており, サンプル規模決定に際し ては有力な根拠となり得る.モデルで必要とするパ ラメータの統計的有意性から見て $300 〜 500$ サンプ ルとしたものや27), パラメータの安定性を直接評 価して, 280〜350 サンプルとしたもの ${ }^{30)}$, また仮 想的データに対するシミュレーション分析を通して， $800 \sim 1000$ 程度は必要としたもの ${ }^{31 ）}$ 等がある.

以上は二肢選択に対する検討であるが，これを目 的地選択モデルのように選択肢数の多い場合に検討 
した例がある ${ }^{32)}$. 選択肢数 41 に対し分析を加え， パラメータの安定性からは变数を限定する必要があ るが，それと集計シェア及び交通量の推計精度等の 点より, 1000 サンプル程度で十分な推計が行える可 能性を示している.

\section{（2） データの作成方法}

モデル構築に用いるデータのうち, 交通サービス データについては, 従来よりアンヶート調査に頼ら ずに，分析者側で適切に設定することが多い。この 理由は, データの信頼性と将来予測に扝ける扱い易 さの 2 点にあり，ネットワーク，メッシュ等による 対処が基本となる. このとき, 如何なる細かさでデ 一タ作成を行う必要があるかについても，(1)と同様 検討例は少なく, 明確な結論は得られていない33). 特にこの問題は, 性格上研究成果となりにくい面が あり, 適用研究の多くが何らかの形式で対処してい るにもかかわらず, 報告例は少ない，交通サービス データを分割して用いる場合や、トリップ長自体が 短い場合等に, より細かな設定が必要となる点は明 らかと言えよう. 具体的な数值として, アクセス交 通に対する $250 \mathrm{~m}$ メッン ${ }^{34)}$, 都市圈の非日常買物 に対する $400 〜 600 \mathrm{~m}^{35)}$ メッシュ等がモデルパラメ 一タの安定性より評価して妥当であると報告されて おり,データ作成時の 1 つの目安と言える.

\section{（3）モデルの構築}

変数同定, パラメータ推定に対する方法論は一般 化されておらず，今だ多少の職人的技術を要求され る状況にあるが，基本的には如何に多くの政策変数 を取り込み，また個人差を表現してモデルの現況再 現性を向上させるために，如何に適切な社会経済特 性を導入できるかといった方向でなされている. 近年の適用研究の蓄積は，もはや変数同定作業を大 幅に軽減しうるほどの情報を提供しており，この点 での整理が望まれる.

一方, パラメータ推定時の計算時間短縮を主たる 目的として, Mc Fadden ${ }^{8)}$ が提案した選択肢のサン
プリング方法については，実証的検討がなされ，選 択肢集合を全体の 3 割程度まで削減した上で，パラ メータ推定を行っても, 統計的には有意な差のない 值が得られることが確認されている32).したがって， 計算費用，データ設定費用等のモデル構築に要する コストを, 特に選択肢集合の大きな状況で削減しう る可能性は高い.

\section{（4）モデルの移転可能性}

非集計行動モデルの移転可能性(Transferability) が確認されれば，様々な点でモデルの利用可能性が 広がるが, この問題に関する統一的な見解は今だに 得られていない. しかし, 近年実証的研究が精力的 に進められた結果 ${ }^{36)}$ ，有用な知見が幾つか得られ ている. 特に地域間移転可能性に対しては，モデル パラメータが地域間で統計的に有意な差を示す場合 であっても，移転される側のサンプルを少数得られ れば，それを用いてモデルを修正することにより， 移転能力を大幅に向上させることが可能である.

したがって，モデル構築のためのサンプル数には 不十分な場合でも, 移転可能性を前提とすれば, 他 地域の信頼度の高いモデルパラメータを用いて，そ れを当該地域により適切に合うように修正した上で， 予測作業が行えることになる，その際，修正に用い るサンプルが 50 票程度でも顕著な改善のなされるこ とが，交通手段選択モデルを例に報告されている ${ }^{37}$ ).

\section{（5）集計方法}

非集計行動モデルの最大の課題とされる集計問題 については, 実証的研究を中心に数多くの検討が加 えられ ${ }^{38)}$ ，一応の成果を得ている，そのうち，集計 方法の比較を試みた研究においては, 分類法を最良 と結論するものが多く, 従来の研究からは, それを 採用することが望ましいと言える，なお現実に将来 值として得られるデータが平均値程度であることを 考えれば，集計精度に依らずとも，上の知見がある 程度妥当であると言えよう. また，交通管理計画等 の短期的予測を行う際には, 数え上げ法を用いるこ 
とも十分に考えられる.

一方，非集計行動モデルの集計誤差を検討した例 も数多く見られるが，そもそも予测誤差が調查から データ作成，モデル構築，集計，移転までの各段階 で生じる誤差より構成されるため，これらを個別に また総合的に評価した上で，始めて集計誤差の十分 な把握が可能になる. 従来の研究のうち, 集計誤差 が支配的との報告はなく, 集計問題が非集計行動モ デルの実用化を大きく左右するといった従来の見解 は，かならずしも絶対的ではないと考えられる.た だし，実証的研究の総てが交通手段選択モデルを対 象としており，非集計行動モデル全般に合てはまる ほどには，研究が進められていない。

\section{4. 集計方法論の新展開}

\section{（1）非集計行動モデルに総量制約を導入する意義}

従来より, 非集計行動モデルを用いて分布交通量 を推計する試みはなされていない。この理由の $1 つ$ は，先にも述べたように，非集計目的地選択モデル 自体の現況再現性がかならずしも良好でなく，これ を改良することに研究の中心があったためと考えら れる $\left.\left.{ }^{39}\right), 40\right)$.また，集計問題を論外とするとき，目 的地の選択確率さえ求められれば，それが取りも直 さず分布交通量を推計できることを意味している.

しかし，分布交通量の推計段階における集計誤差 の問題は，前章にも述べたように，現時点で解決さ れているとは言えず，特に目的地選択に絞って分析 した例はない. OD表を推計しても, 誤差が大きく, 成果として提示するに至らなかった研究が，少なか らず存在するといった邪推も，あながち誤りではな いと思われる.

したがって, 分布交通量推計の段階に対し, より 精度の高い推計を可能とする集計方法論を開発する ことは, 非集計目的地選択モデルの説明力を高める 努力と同様，もしくはそれ以上に重要で意義がある ことと考える.

ところで，そもそも非集計行動モデルを用いて，
分布交通量を推計する動機を, 如何なる点に求めら れるであろうか. これには少なくとも次の 3 点を挙 げられよう. すなわち, (1)各トリップの発地をゾー ンとは無関係に細かく押えることが出来るため，モ デル構築段階で内内交通の問題を軽減できる. (2)非 集計交通手段選択モデル等と組み合わせ，その段階 と斉合するようにモデル構築を行うことにより, 数 多くの政策変数を取り込むことが出来る. (3)モデル 構築に要するサンプル数が少なく済む. 特に(3)に いては，ランダムサンプルに限らず，モデルに移転・ 拡大可能性が認められれば，一部の地域のデータで 構築したモデルによって，全域の OD 表を推計する ことも可能になる.

以上に示した利点を生かすためにも，新たな方法 論を開発し，非集計行動モデルによる分布交通量の 推計を実用化するごとは急務と考える. 本章では, この問題に対して新たなアプローチを加える. それ は，モデルの集計段階で総量制約を導入する方法で ある41) .

従来の非集計行動モデルの考え方は, 発生頻度か ら目的地，交通手段，経路に至る総ての段階を，同 時型もしくは段階型のモデルで構築した上で同時選 択確率を求めれば，対象人口を与えることによって 各段階の交通量を算出できるものである. しかしな がら, 目的地選択モデルの問題に加え, 発生頻度選 択モデルの適用性も不明確なままであり，モデル開 発以来優れた成果はほとんど報告されていない.

このような研究状況を考えるとき, 総ての段階に 非集計行動モデルを適用するのではなく，分布・分 担といった一部分に用いる方法を開発することが， より実用的であると言える，ただし，その場合には， 他の異なる形体のモデルより得られる推計値と, 非 集計行動モデルを集計することによって求まる値と の間に斉合性を確保する必要が生じる，本章で提案 する方法論は，正にこのような状況を想定し，総量 データが与えられた条件下で，それを反映するよう に非集計行動モデルを修正して，集計精度を高める ためのものであり，特に現況データに対しては，効 
用関数の改良としての意味あいを強く持つ.

\section{（2）総効用最大化による分布交通量の集計予測法}

本研究で開発する集計予測方法の基本的な考えは, 与えられた種々の制約条件のもとで，母集団におけ る効用を最大とするように，分布交通量を求めるも のである.それを以下に説明する.

1. で示した確率効用を，ここでは次のように表現 する.

$$
U_{j n \mid i}=V_{j n \mid i}+\varepsilon_{j n \mid i}
$$

上式で $i, j$ はトップの発地, 着地を表わし, $n$ は 個人を表わす. $\varepsilon_{j n \mid i}$ がガンベル分布に従うとき， (4-1) より求まる最大効用の期待値 $M U_{n \mid i}$ は,

$$
M U_{n \mid i}=E\left(\max _{j \in D} U_{j n \mid i}\right)=\frac{1}{\lambda} \ln \sum_{j \in D} e^{\lambda V_{j n \mid i}}
$$

と計算できる. $M U_{n \mid i}$ は利用者便益 (Consumerś Surplus $)^{6)}$, 満足関数 (Satisfaction Function) ${ }^{25}$ ), アクセシビリティー (Accessibility $)^{7)}$ などと称さ

れ, 確率変動を考慮した効用の水準を表わす.

ここで，(4-2) をもとに，母集団における $M U$ の 算出を試みる。そのためには, 集計作業が必要とな るが，本研究では分類法を用いて集計を行う。分類 法は, 代表的な 5 種類の方法のうち, 簡便法と数元 上げ法とを特殊例に持つ一般性を有する方法であり， その有効性は前章に概説した. 発地 $i$ ごとに層 $g$ を 設定し, 各層の効用水準を $M U_{g \mid i}$ とおけば, 発地 $i$ の集団の効用 $M U_{i}$ は,

$$
\begin{aligned}
& M U_{i}=t_{i} \cdot \sum_{g} w_{i g} \cdot M U_{g \mid i} \\
& M U_{g \mid i}=\frac{1}{\lambda} \ln \sum_{j \in D} e^{\lambda V_{j 0 \mid i}}
\end{aligned}
$$

\section{によって表現できる.}

$w_{i g}$ は各層の構成比を表わし, $t_{i}$.は発生トリップ 数を表わす.（4-3）は効用が加法的であることを 意味しており，これを用いれば，母集団の効用を，

$$
M U=\sum_{i \in D} M U_{i}
$$

と表現できる.

ここで, $M U_{g \mid i}$ の性質より,

$$
\frac{\partial M U_{g \mid i}}{\partial V_{j g \mid i}}=P_{j g \mid i}=\frac{e^{\lambda V_{j g \mid i}}}{\sum^{\prime} \in D} e^{\lambda V_{j \mid i}^{\prime}}
$$

によって選択確率 $P_{j g \mid i}$ が算出できるが7), 上式が口 ジットモデルになるのは, 効用の確率項をガンベル 分布に従うと仮定したことによる（4-6) 式を変形 ᄂ,

$$
\ln P_{j g \mid i}=\lambda V_{j g \mid i}-\ln \sum_{j^{\prime} \in D} e^{\lambda V_{j^{\prime} g \mid i} \ldots \ldots}
$$

とした上で, $P_{j g \mid i}$ を用いて両辺の期待値をとると,

$$
\begin{aligned}
& \sum_{j \in D} P_{j g \mid i} \ln P_{j g \mid i} \\
& =\sum_{j \in D} P_{j g \mid i}\left(\lambda V_{j g \mid i}-\ln \sum_{j^{\prime} \in D} e^{\lambda V_{j^{\prime} \mid i}}\right) \\
& =\lambda \sum_{j \in D} P_{j g \mid i} V_{j g \mid i}-\ln \sum_{j^{\prime} \in D} e^{\lambda V_{j^{\prime}, \mid i}}
\end{aligned}
$$

を得る.ここで (4-8)を(4-5)に代入すれば,

$$
\begin{aligned}
M U= & \sum_{i \in D} t_{i} \cdot \cdot \sum_{g} w_{i g} \frac{1}{\lambda} \ln \sum_{j \in D} e^{\lambda V_{j^{\prime} \mid i}} \\
= & \sum_{i \in D} t_{i} \cdot \sum_{g} w_{i g}\left(-\frac{1}{\lambda} \sum_{j \in D} P_{j g \mid i} \ln P_{j g \mid i}\right. \\
& \left.+\sum_{j \in D} P_{j g \mid i} V_{j g \mid i}\right) \cdots \cdots \ldots \ldots \ldots \ldots . . . \cdots \cdots
\end{aligned}
$$

を最終的に得る.

$M U$ は個人の効用を積み上げることによって定ま り, 既にモデルのパラメータが推定されていれば, 特性值の各層における平均値を代入することにより 算出できる.これが先に述べた集計作業であるが, そこで実現される交通量の分布パターンは，かなら ずしも所与の值を反映しない，たとえば，発生交通 量に加え集中交通量も既知なる場合に，非集計目的 地選択モデルより推計される分布交通量をもとに集 中交通量を算出しても，それが所与の值と異なる.

このような例に代表される問題を合理的に解決し, 交通量に関する斉合性を確保した上で，分布交通量 自体の推計精度をも高めるために, 本研究では, こ れを次のように考える，すなわち，集団の交通流動 は，交通量に関して与えられた制約を満たすよう 
非集計行動モデルとその実用性

に決まるが，その場合にも，個人の効用を積み上げ ることによって求まる $M U か ゙ ，$ 最大となるように分 布パターンが求まると考える.

（4-9）を用いて, 次の最大化問題,

$$
\begin{aligned}
\max _{P_{j g \mid i}} M U= & \sum_{i \in D} t_{i} \cdot \sum_{g} w_{i g}\left(-\frac{1}{\lambda} \sum_{j \in D} P_{j g \mid i} \ln P_{j g \mid i}\right. \\
& \left.+\sum_{j \in D} P_{j g \mid i} V_{j g \mid i}\right) \cdots \cdots \cdots(4-10)
\end{aligned}
$$

$$
\text { s.t. } \sum_{i \in D} t_{i} \cdot \sum_{g} w_{i g} P_{j g \mid i}=t_{\cdot j}, \forall j \in D \quad(4-11)
$$

を考える.（4-11）は集中量に関する制約であり, $t . j$ は所与の集中量である. (4-10) は新たな分布パ ターンを求めるために, $P_{j g \mid i}$ がロジットモデルで表 現できる前提を外した上で， $M U を ~ P_{j g \mid i}$ について 最大化することを意味し, ラグランジュの未定乗数 $\gamma_{j}, \eta_{i g}$ を導入すると,

$$
\begin{aligned}
& L(\boldsymbol{P}, \boldsymbol{r}, \boldsymbol{\eta}) \\
& =\sum_{i \in D} t_{i} \cdot \sum_{g} w_{i g}\left(-\frac{1}{\lambda} \sum_{j \in D} P_{j g \mid i} \ln P_{j g \mid i}\right. \\
& \left.+\sum_{j \in D} P_{j g \mid i} V_{j g \mid i}\right)+\sum_{j \in D} \gamma_{j}(t \cdot j \\
& \left.-\sum_{i \in D} t_{i} \cdot \sum_{g} w_{i g} P_{j g \mid i}\right) \\
& +\sum_{i \in D} \sum_{g} \eta_{i g}\left(\sum_{j \in D} P_{j g \mid i}-1\right) \cdots(4-12) \\
& \frac{\partial L}{\partial P_{j g \mid i}}=t_{i} \cdot w_{i g}\left(-\frac{1}{\lambda} \ln P_{j g \mid i}-\frac{1}{\lambda}\right. \\
& \left.+V_{j g \mid i}-\gamma_{j}+\eta_{i g}\right)=0 \\
& \frac{\partial L}{\partial \gamma_{j}}=t \cdot j-\sum_{i \in D} t_{i} \cdot \cdot \sum_{g} w_{i g} P_{j g \mid i}=0 \\
& \frac{\partial L}{\partial \eta_{i g}}=\sum_{j \in D} P_{j g \mid i}-1=0
\end{aligned}
$$

を得る. (4-13), (4-15) より直ちに,

$$
P_{j g \mid i}=\frac{e^{\lambda\left(V_{j g \mid i}-\gamma_{j}\right)}}{\sum_{j^{\prime} \in D} e^{\lambda\left(V_{j^{\prime} g \mid i}-\gamma_{j^{\prime}}\right)}}
$$

が得られる.ここで最大値における $M U, P_{j g \mid i}, r_{j}$, をそれぞれ, $M U^{*}, P_{j g \mid i}^{*}, \gamma_{j}^{*}$ とおけば， シャドゥ プライス $r_{j}^{*}$ は,

$$
\frac{\partial M U^{*}}{\partial t_{\cdot j}}=\gamma_{j}^{*}
$$

によって表現でき, 所与の集中交通量 $t \cdot{ }_{j}$ の変化に 対する, 総効用の最大值 $M U^{*}$ の変化を意味するこ とがわかる. したがって， $\gamma_{j}^{*}$ は限界効用の次元を 持ち, (4-16) で示される新たな確率 $P_{j g \mid i}$ が，層ご とに定まる効用 $V_{j g \mid i}$ と，交通量データより定まり層 及び発地に依らない限界効用 $\gamma_{j}{ }^{*}$ との両者によって 求まることになる.

$$
\begin{aligned}
& r_{j}^{*} \text { は, }(4-14) \text { より, } \\
& f_{j}(\boldsymbol{\gamma})=\sum_{i \in D} t_{i} \cdot \sum_{g} w_{i g} \frac{e^{\lambda\left(V_{j g \mid i}-\gamma_{j}\right)}}{\sum_{j^{\prime} \in D} e^{\lambda\left(V_{j^{\prime} g \mid i}-\gamma_{j}^{\prime}\right)}-t \cdot j}
\end{aligned}
$$

とおき, $f_{j}(\boldsymbol{r})=0(\forall j \in D)$ を満たすように, 逐次 計算を用いて解けば良い41).

この結果, $r_{j}{ }^{*}$ が定まり，集中量制約下で総効用 を最大とする $P^{*}{ }_{j g \mid i}$ を求められ,

$$
\widehat{t}_{i j}=t_{i} \cdot \sum_{g} w_{i g} P^{*}{ }_{j g \mid i}
$$

によって, 集中量制約を満たす分布交通量を得るこ とができる.

\section{（3）本方法の適用可能性}

前節に提案した集計予測方法では，効用関数自体 は比較的少数のサンプルより同定しうるが，それを 用いてそのまま集計を行っても，行通現象を必ず しも的確に反映し得ない点に着目し，信頼性の高い 集計データが得られている場合に，それを用いるこ とによって,より精度の高い推計が可能になると考 えた. 行通の流動は, 全体での総効用が最大となる ように定まると見なし，それを制約条件下で最大化 することより解が得られた。

したがって, 特に現況の総量データ（発生, 集中 量等）が他の調査より精度高く求められている場合 等に，モデルを改善する目的で本方法を用いること は，非常に有意義であると考える．また将来予測時 には，モデル間の斉合性を確保するために有効な方 
屋井：

法と言える.

ところで, (4-10) は形式上, エントロピー最大 化問題と一致するが，これは集計段階で効用関数 $V_{j g \mid i}$ を確定值としており，MUの最大化を $P_{j g \mid i}$ によ って行う必要から生じた結果である. エントロピー 最大化と最大効用の期待值との等価性は, ロジット モデルに対し既に確認されているが42)，本研究では この問題を恒等式の変形により, 形式的に示したこ とになる。

本方法を奏際のデータに適用した例は, 森地・屋 井・田村 ${ }^{41)}$, 森地・屋井・平井 $\left.{ }^{43}\right)$ で報告されており, 都市圏規模の OD 表を推計する場合にも，非常に良 好な結果が得られている. 具体的内容はこれらの論 文にゆずるが，ここでは，本方法より求まる OD表 が，既存の手法であるフレータ法と比べ如何に異な るかを簡単な例で示す. 付表- 1 は非集計目的地選 択モデルを集計し，OD 表を推計する際に，本方法 を適用したものである. 一方，付表－2 は本方法を 適用することなく，非集計目的地選択モデルを集計 して求めた OD 表をもとに, フレータ法より推計し たものである. 両者とも観測值との相関係数は 0.96 と同等であるが，誤差については前者が若干少ない. この点より手法の優劣を論じることに大きな意味は ないが，これらの検討を通して本方法の妥当性が検 証できたと考える.

\section{（4）本方法の一般化について}

(4-11)に示した制約条件については,データの 信頼性に着目して定めることが重要であるが，例え ば所要ゾーンよりも粗いゾーン間の分布交通量が得 られている場合等, (4-11) のかわりに,

$$
\sum_{i \in D_{k}} \sum_{j \in D_{l}} \sum_{g} t_{i} \cdot \cdot w_{i g} P_{j g \mid i}=t_{k l} \cdots(4-20)
$$

なる制約を導入すれば, 結局,

$$
P_{j g \mid i}=\frac{e^{\lambda\left(V_{j g \mid i}-\mu_{l(j) \mid k}\right)}}{\sum_{j^{\prime} \in D} e^{\lambda\left(V_{j^{\prime} g \mid i}-\mu_{l\left(j^{\prime}\right) \mid k}\right)}}
$$

を得，同様な方法により未定乗数 $\mu_{l \mid k}$ を定めた上で，
所要ゾーン間の OD 表を推計できる ${ }^{44)}$. 上式で $D_{k}$, $D_{l}$ はそれぞれ粗いゾーン $k, l$ に含まれる所要ゾーン の集合を表わし， $l(j)$ は $j$ を含む粗いゾーンを意 味する．例えば，国勢調査より得られる市町村間 のOD表と, 別途調查より得た少数の非集計データ とを用いて，より細かな OD 表を推計する場合など が本例に相当する. また本方法を，これ以外の異な る対象，状況に適用できるように一般化することは， さほど困難ではないと考える ${ }^{32)}$.

おわりに

本研究は, 非集計行動モデルの今後の研究方向に 対して，1つの指針を与えることを目標に掲げ，進 められた. そのため，モデル開発と実用化のための 研究とを，体系的に整理することから始めた。

近年のモデル開発の動向を, 広義の非集計行動モ デル，すなわち個人行動モデルとして捉えた上で， 著者の開発によるモデルをも加えて体系的に表わし た. その結果，当面の実用性を前提としたモデルの 開発・適用に留まることなく，より現実的な仮説に 基づき，行動をより的確に反映するモデルの開発の 必要性が指摘された. 従来より認識される非集計と いう語意が，集団としての現象を構成する各要素の 動きに着目することのみにあるとしても，サンプル の有効利用を計れる大きな意義を認められるが，こ れをより行動的なモデルに発展させる努力が重要と 考える.

一方, 非集計行動モデルの実用化については, 現 在正に研究が進行しており, 総括するには若干時期 尚早と言えようが, 近年の精力的な研究成果の蓄積 は, 数多くの有益な情報を提供してくれた. 特に本 研究では, 講習会以後の成果を中心に, 断片的なが らも整理を試みており, サンプル数問題等に対する 目安が定まりつつある状況をうかがえる。

また，非集計行動モデルの実用化を，交通手段選 択に限らず分布交通量推計の段階にまで広げ，その 適用領域を今一度拡大するため, 本研究では, 新た な方法論を提案し，それを前章にまとめた．別途収 
集した集計データをモデル改良の目的で用いるため， 従来の集計モデル等との関連も取りざたされようが, 個人の行動をそのまま積み上げても，それが集団の 行通の流れと差のある状況，すなわち合成の䘫謬と も言える問題は，従来の集計誤差の問題とも異なり， 適切に対処する必要があろう. 本研究で示した方法 論は，この問題に対する 1 つのアプローチと言え， 今後, 改良を重ねることによって, 個人の行動と集 団の流動とのギャップを埋める方法論として精緻化 していくことが可能と考える.

なお, 東京工業大学工学部, 森地茂 助教授には, 著者がこの研究を進める上で終始適切なご指導を頂 きました.ここに記して深謝の意を表する次第であ ります、また，未熟な筆者に，このような研究発表 の機会を与えて下さった, 土木計画学研究委員会の 諸先生に感謝致します.

【注 $1 】$ 効用の最大值すら閾值を越えない確率を,

$$
\begin{aligned}
& \operatorname{Prob}\left[\max _{j \in C} U_{j} \leq U_{T}\right] \\
& \quad=\operatorname{Prob}\left[V_{T}+\varepsilon_{T} \geq \max _{j \in C}\left(V_{j}+\varepsilon_{j}\right)\right]
\end{aligned}
$$

と定義する. ここで閾値 $U_{T}\left(=V_{T}+\varepsilon_{T}\right)$ もランダ ム項 $\varepsilon_{T}$ により確率変動すると考えている. $\varepsilon_{i}$ 及び $\varepsilon_{T}$ が,

$$
\begin{aligned}
& \operatorname{Prob}\left[\varepsilon_{i} \leq \varepsilon\right]=e^{-e^{-\left(\varepsilon+\alpha_{i}\right)}} \\
& \operatorname{Prob}\left[\varepsilon_{T} \leq \varepsilon\right]=e^{-e^{-\left(\varepsilon+\alpha_{T}\right)}}
\end{aligned}
$$

なるガンベル分布に従うと仮定すれば,

$$
\begin{aligned}
& \operatorname{Prob}\left[\max _{j \in C} \varepsilon_{j} \leq \varepsilon\right]=e^{-e^{-(\varepsilon+\alpha)}}, \\
& \alpha=\ln \sum_{j \in C} e^{-\alpha_{j}}
\end{aligned}
$$

となり, (A-1) は,

$$
\begin{gathered}
\operatorname{Prob}\left[\max _{j \in C} U_{j} \leq U_{T}\right]=\frac{e^{V_{T}-\alpha_{T}}}{e^{\alpha^{\prime}}+e^{V_{T}-\alpha_{T}}}, \\
\alpha^{\prime}=\ln \sum_{j \in C} e^{V_{j}-\alpha_{j}} \quad \cdots \cdots \cdots \cdots \cdots \cdots \cdots
\end{gathered}
$$

と求まる. 上式の定数項 $\alpha_{j}$ を $V_{j}$ に含め, $\alpha_{T}=-$ $\ln \mathrm{A}$ ( A は選択肢数 ) とおけば,

$$
\operatorname{Prob}\left[\max _{j \in C} U_{j} \leq U_{T}\right]=\frac{e^{V_{T}+\ln A}}{\sum_{j \in C} e^{V_{j}}+e^{V_{T}+\ln A}}
$$

と書き換えられる.ここで, 最大効用ですら閾値を 越えない場合には選択が無差別となると考え，その ときの選択確率を，

$$
P_{R}(i \mid C)=\frac{1}{A}
$$

と表わし，一方それ以外では同時評価されると考え，

$$
P_{L}(i \mid C)=\frac{e^{V_{i}}}{\sum_{j \in C} e^{V_{j}}}
$$

なるMNL モデルで表わす．このとき，選択肢 $i$ を 選ぶ確率は，

$$
\begin{aligned}
& P(i \mid C)= \operatorname{Prob}\left[\max _{j \in C} U_{j} \leq U_{T}\right] \cdot P_{R}(i \mid C) \\
&+\operatorname{Prob}\left[\max _{j \in C} U_{j} \geq U_{T}\right] \cdot P_{L}(i \mid C) \\
&=\frac{e^{V_{T}+\ln A}}{\sum_{j \in C} e^{V_{j}}+e^{V_{T}+\ln A}} \cdot \frac{1}{A} \\
&+\frac{\sum_{j \in C} e^{V_{j}}}{\sum_{j \in C} e^{V_{j}}+e^{V_{T}+\ln A}} \cdot \frac{e^{V_{i}}}{\sum_{j \in C} e^{V_{j}}} \\
&=\frac{e^{V_{i}}+e^{V_{T}}}{\sum_{j \in C}\left(e^{V_{j}}+e^{V_{T}}\right)} \quad \cdots \cdots \cdots \cdots \cdots \cdots \cdots \cdots \cdots(\mathrm{A}-9)
\end{aligned}
$$

と表わされる.

また無差別の場合にも選択に偏向性があると考え，

$$
P_{R}(i \mid C)=S_{i}, \quad \sum_{j \in C} S_{j}=1
$$

とおけば, $P(i \mid C)$ は結局,

$$
P(i \mid C)=\frac{e^{V_{i}}+S_{i} e^{V_{T}}}{\sum_{j \in C} e^{V_{j}}+e^{V_{T}}}
$$

と求まる.ただし，このときは $\ln A$ を $V_{T}$ に含めて 
【注 2 まず，効用の最小值の分布を考える. ラ ンダム効用 $U_{j}$ を,

$$
U_{j}=V_{j}+\varepsilon_{j}, \quad \forall j \in C
$$

で表わすとき， $\varepsilon_{j}$ は $V_{j}$ のまわりに分布するので, 最大効用を考える場合と同様に，最小効用について も定義できる. すなわち, 最小効用が任意の值 $z$ よ り大きい確率を,

$$
\operatorname{Prob}\left[\min _{j \in C} U_{j} \geq z\right]=\operatorname{Prob}\left[U_{j} \geq z, \forall j \in C\right]
$$

によって表わし, 確率項 $\varepsilon_{j}$ が選択肢間で相互に独立 に,

$$
\operatorname{Prob}\left[\varepsilon_{j} \geq \varepsilon\right]=e^{-e^{\lambda \varepsilon+\beta_{j}}}, \lambda>0
$$

に従うと考える.なお， $\varepsilon_{j}$ がガンベル分布に従うと 考えれば，(A-15）の確率は，

$$
\begin{gathered}
\operatorname{Prob}\left[\varepsilon_{j} \geq \varepsilon\right]=1-\operatorname{Prob}\left[\varepsilon_{j}<\varepsilon\right] \\
\quad=1-e^{-e^{-\left(\lambda \varepsilon+\beta_{j}\right)}} \quad \ldots \ldots \ldots \ldots \ldots \ldots \ldots
\end{gathered}
$$

と求まるが，後述する積分計算を容易にするため, ( A - 15) すなわち, ガンベル分布の軸対象を取っ たもので当該分布を近似する.（A-15）のもとでは,

$$
\begin{gathered}
\operatorname{Prob}\left[\min _{j} U_{j} \geq z\right]=\prod_{j \in C} \operatorname{Prob}\left[U_{j} \geq z\right] \\
=e^{-e^{\lambda z+\beta}}, \beta=\ln \sum_{j \in C} e^{-\lambda V_{j}+\beta_{j}}
\end{gathered}
$$

と求まり, したがって最小効用の期待値は, 積分計 算を行い,

$$
\begin{aligned}
E\left(\min _{j \in C} U_{j}\right) & =\int_{-\infty}^{\infty} z d \operatorname{Prob}\left[\min _{j \in C} U_{j} \geq z\right] \\
& =-\int_{-\infty}^{\infty} z \cdot e^{\lambda z+\beta} \cdot e^{-e^{\lambda z+\beta}} d z \\
& =-\frac{1}{\lambda} \ln \sum_{j \in C} e^{-\lambda V_{j}+\beta_{j}}
\end{aligned}
$$

によって表わせる.（A-18）は，

$$
\begin{gathered}
V_{j}-\frac{\beta_{j}}{\lambda}>E\left(\min _{j \in C} U_{j}\right), \forall j \in C \\
\ldots \ldots \ldots \ldots \ldots \\
E\left(\min _{j \in C} U_{j}\right) \geq E\left(\min _{j \in C^{\prime}} U_{j}\right), \quad C \subset C^{\prime}
\end{gathered}
$$

を満たし, 選択肢を追加すれば最小効用の期待值が 低下することを意味する.

ここで $C(\bar{i})$ を選択肢集合 $C$ から要素 $i$ を除いた 集合とする.このとき，

$$
\begin{aligned}
R_{i} & =E\left(\min _{j \in C(\bar{i})} U_{j}\right)-E\left(\min _{j \in C} U_{j}\right) \\
& =\frac{1}{\lambda}\left[\ln \sum_{j \in C} e^{-\lambda V_{j}+\beta_{j}}-\ln \sum_{j \in C(\bar{i})} e^{-\lambda V_{j}+\beta_{j}}\right]
\end{aligned}
$$

は選択肢 $i$ 以外の総ての要素が既に集合に加えられ

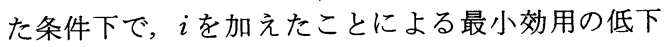
分を表わす。また言葉を変えれば, 総てを集合に加 えた状態で, もしiを加えていなければ，如何に最 小効用の低下を防げたかを表わす. これを $i$ 集合 に加える際の抵抗値と考え, 効用 $V_{i}$ よりこれを差し 引いた值で選択が決まると考える.

$$
P(i \mid C)=\frac{e^{\lambda\left(V_{i}-\alpha R_{i}\right)}}{\sum_{j \in C} e^{\lambda\left(V_{j}-\alpha R_{j}\right)}}, \quad \alpha>0
$$

上式で選択確率を定義すれば，結局，

$$
P(i \mid C)=\frac{e^{\lambda V_{i}}\left(\sum_{j \in C(\bar{i})} e^{-\lambda V_{j}+\beta_{j}}\right)^{\alpha}}{\sum_{j \in C} e^{\lambda V_{j}}\left(\sum_{j^{\prime} \in C(\bar{j})} e^{-\lambda V_{j^{\prime}}+\beta_{j^{\prime}}}\right)^{\alpha}}
$$

と求まり, 更に $\alpha=1$ の場合を考えれば,

$$
P(i \mid C)=\frac{\sum_{j \in C(\bar{i})} e^{\lambda V_{i}-\lambda V_{j}+\beta_{j}}}{\sum_{j \in C} \sum_{j^{\prime} \in C(\bar{j})} e^{\lambda V_{j}-\lambda V_{j^{\prime}}+\beta_{j^{\prime}}}}
$$

を得る。 
付表 - 1 本研究の方法により推計したOD表

\begin{tabular}{|r|rrrrrrrrrrrrr|}
\hline O & \multicolumn{1}{c}{1} & 2 & 3 & 4 & \multicolumn{1}{c}{5} & \multicolumn{1}{c}{6} & 7 & 8 & 9 & 10 & 11 & $t_{i} \cdot$ \\
\hline 1 & 968 & 216 & 279 & 219 & 74 & 332 & 54 & 117 & 32 & 112 & 14 & 2,415 \\
2 & 1,502 & 1,458 & 618 & 207 & 143 & 1,133 & 253 & 289 & 66 & 189 & 21 & 5,879 \\
3 & 1,955 & 758 & 1,347 & 494 & 199 & 941 & 213 & 973 & 160 & 495 & 45 & 7,580 \\
4 & 1,404 & 299 & 564 & 850 & 269 & 752 & 120 & 350 & 112 & 664 & 59 & 5,443 \\
5 & 805 & 259 & 287 & 385 & 842 & 1,193 & 101 & 191 & 63 & 314 & 78 & 4,518 \\
6 & 1,170 & 643 & 422 & 307 & 463 & 4,140 & 239 & 305 & 106 & 285 & 40 & 8,120 \\
7 & 1,338 & 910 & 666 & 326 & 188 & 1,397 & 1,478 & 493 & 115 & 307 & 39 & 7,257 \\
8 & 1,437 & 610 & 1,201 & 448 & 212 & 989 & 256 & 1,520 & 365 & 670 & 60 & 7,767 \\
9 & 813 & 281 & 494 & 272 & 124 & 559 & 118 & 726 & 1,416 & 860 & 88 & 5,750 \\
10 & 1,445 & 455 & 782 & 1,040 & 389 & 1,071 & 202 & 735 & 370 & 3,590 & 299 & 10,378 \\
11 & 327 & 81 & 116 & 161 & 151 & 280 & 38 & 85 & 61 & 318 & 443 & 2,059 \\
\hline$t . j$ & 13,163 & 5,970 & 6,776 & 4,709 & 3,052 & 12,786 & 3,072 & 5,782 & 2,865 & 7,803 & 1,188 & 67,166 \\
\hline
\end{tabular}

付表- 2 フレータ法により推計したOD表

\begin{tabular}{|r|rrrrrrrrrrrr|r|}
\hline $\mathrm{O}$ & \multicolumn{1}{c|}{1} & 2 & 3 & \multicolumn{1}{c}{5} & \multicolumn{1}{c}{5} & \multicolumn{1}{c}{6} & 7 & 8 & 9 & 10 & 11 & $t_{i}$. \\
\hline 1 & 963 & 215 & 279 & 219 & 74 & 334 & 54 & 118 & 32 & 112 & 14 & 2,415 \\
2 & 1,501 & 1,459 & 616 & 207 & 143 & 1,140 & 255 & 289 & 62 & 186 & 20 & 5,879 \\
3 & 1,951 & 756 & 1,348 & 498 & 200 & 944 & 214 & 976 & 154 & 495 & 44 & 7,580 \\
4 & 1,401 & 300 & 568 & 849 & 268 & 755 & 120 & 353 & 108 & 661 & 60 & 5,443 \\
5 & 813 & 260 & 289 & 385 & 849 & 1,186 & 101 & 190 & 59 & 308 & 78 & 4,518 \\
6 & 1,175 & 644 & 424 & 308 & 462 & 4,143 & 236 & 305 & 101 & 281 & 40 & 8,120 \\
7 & 1,348 & 914 & 668 & 325 & 188 & 1,389 & 1,483 & 491 & 110 & 302 & 39 & 7,257 \\
8 & 1,442 & 614 & 1,198 & 450 & 212 & 997 & 256 & 1,523 & 350 & 666 & 60 & 7,767 \\
9 & 789 & 273 & 484 & 269 & 120 & 556 & 114 & 718 & 1,473 & 865 & 88 & 5,750 \\
10 & 1,450 & 455 & 785 & 1,035 & 386 & 1,067 & 201 & 735 & 358 & 3,608 & 300 & 10,378 \\
11 & 330 & 80 & 117 & 162 & 150 & 275 & 38 & 84 & 58 & 318 & 447 & 2,059 \\
\hline$t . j$ & 13,163 & 5,970 & 6,776 & 4,709 & 3,052 & 12,786 & 3,072 & 5,782 & 2,865 & 7,803 & 1,188 & 67,166 \\
\hline
\end{tabular}

\section{参 考 文 献}

1) Koppelman, F.S. : Guidelines for Aggregate Travel Prediction Using Disaggregate Choice Models, Transportation Research Record 610, pp. 19-24, 1976.

2) Mc Fadden, D. : Conditional Logit Analysis of Qualitative Choice Behavior. In Frontiers in Econome trics, ed. P. Zarembka, Academic Press, pp. 105$142,1974$.

3) Mc Lynn, J. : Disaggregate Mode Choice Models of
Fully Competitive Type, DTM Report, 1973.

4) Ben-Akiva, M.E. : Structure of Passenger Travel Demand Models, Transportation Research Record 526, pp. 26-42, 1974.

5) Daly, A.J. \& S. Zachary. : Improved Multiple Choice Models. In Determinants of Travel Choice, ed. D.A. Hensher and Q. Dalvi, A Saxson House Reprint, pp. 335-357, 1978.

6) Williams, H.C.W.L. : On the Formation of Travel Demand Models and Economic Evaluation Measures of User Benefit, Envioronment and Planning 
A. Vol. 9, pp. 285-344, 1977.

7) Ben-Akiva, M.E. \& S.R. Lerman. : Disaggregate Travel and Mobility-Choice Models and Measures of Accessibility. In Behavioural Travel Modelling, ed. D.R. Stopher, Croom London, pp. 279-318, 1979.

8) Mc Fadden, D. : Modelling the Choice of Residential Location. In Spatial Interaction Theory and Planning Models, ed. A. Karlqvist etal., North-Holland, Amsterdam, 1978.

9) Mc Fadden, D. : Econometric Models of Probabilistic Choice. In Structural Analysis of Discrete Data with Ecomometric Applications, ed. C.F. Manski and D.Mc Fadden, The MIT Press, pp. 198-272, 1981.

10）河上省吾 ·広畠康裕・溝上章志 : 意識データに基づく 交通機関の転換率モデル構築の試み, 土木学会・土木 計画学研究, 論文集 I, pp. 11-18, 1984.

11）宮本和明：立地選択モデルー 非集計行動モデルの土 地利用モデルへの応用一，土木学会土木計画学講習 会テキスト 15, pp. 161-174, 1984.

12) Krishnan, K.S. : Incorporating Thresholds of Indifference in Probabilistic Choice Models, Management Science, Vol. 23, No. 11, pp. 1124-1233, 1977.

13）加藤 晃・森杉壽芳・阿佐真一：Mogit Model によ る住宅立地行動の一考察; 第36回土木学会年講, 第 4 部門, pp. 373-374, 1981.

14) Manski, C.F.: The Structure of Random Utility Models, Theory and Decision 8, pp. 229-254, 1977.

15) Gaudry, M.J.I. \& M.G. Dagenais. : The Dogit Model, Transportation Research, Vol.13B, pp.105-112, 1979.

16) Hensher, D.A. \& L.W. Johnson. : Applied DiscreteChoice Modelling, A Halsted Press Books, 1981.

17）宮本和明・宮地淳夫：非集計型住宅タイプ選好モデル, 都市計画学会, 学術研究発表論文集, 第 17 号, pp.139144, 1982.

18) Richardson, A. : Search Models and Choice Set Generation, Transportation Reseach, Vol. 16 A, pp. 403-420, 1982.

19) Landau, U., J.N. Prashker \& Alrern. : Evaluation of Activity Constrained Choice Sets to Shopping Destination Choice Modelling, Transportation Reserach, Vol.16 A, pp. 199-208, 1982.

20) Tversky, A. : Elimination by Aspects; A Theory of
Choice, Psychological Review 79(4), pp.281-299, 1972.

21) Tversky, A \& S. Sattath. : Preference Trees, Psychological Review 86, pp. 542-573, 1977.

22) Foerster, J.F. : Mode Choice Decision Process Models; A Comparison of Compensatory and NonCompensatory Strutures, Transportation Research, Vol. 13 A, pp. 17-28, 1979.

23) Recker, W.W. \& T.F. Golob. : A non-Compensatory Model of Transportation Behavior Based on Sequential Consideration of Attributes, Trasportation Research, Vol. 13B, pp. 269-280, 1979.

24）森地 茂・酒井通雄・井原勝美 : 大都市圏における交 通機関選択分析, 土木計画学研究発表会講演集 I, pp. 58-65, 1979 .

25) Daganzo, C. : Multinomial Probit; The Theory and It's Application to Demand Forecasting, Academic Press, 1979.

26) Sheffi, Y. :Estimating Choice Probabilities among Nested Alternatives, Transportation Research, Vol. 13 B, pp. 189-206, 1979.

27）森地 茂・屋井鉄雄：非日常交通への非集計行動モデ ルと選択肢別標本抽出法の適用性, 土木学会論文報告 集, 第342号, pp. 161-170, 1984.

28) Manski, C.F. \& S.R. Lerman.: The Estimation of Choice Probabilities from Choice Based Samples, Econometrica, Vol. 45, No. 8, pp. 1977-1988, 1977.

29) Manski, C.F. \& D. Mc Fadden. : Alternative Estimators and Sample Designs for Discrete Choice Analysis. In Structural Analysis of Discrete Data with Econometric Applications, ed. C. F. Manski and Mc Fadden, The MIT Press, pp. 2-50, 1981.

30) 太田勝敏 : 非集計行動モデルの交通計画への適用に関 する研究 (II), 東京大学工学部, 太田研究室, 1981.

31）桐越 信・塚本直幸: シミュレーションデータによる 非集計ロジットモデルの誤差解析, 土木計画学研究発 表会講演集 5,pp. 450-461，1983.

32）屋井鉄雄：非集計行動モデルによる交通需要予測手法, 東京工業大学工学博士論文, 1985.

33) 山形耕一: 非集計モデルのための調査とデータ作成, 土木学会土木計画学講習会テキスト15, pp. 67-103, 1984.

34）原田 昇：鉄道経路選択モデルにおける集計レベルに 関する分析，第 38 回土木学会年講，第 4 部門，pp. 39- 
40, 1983.

35）森地 茂・屋井鉄雄・田村 亨: 非集計行動モデルの 構築に要する交通サービスデータの精度に関する検討, 日本都市計画学会, 日本都市計画学会学術研究論文集 20, pp. 271-276, 1985.

36）屋井鉄雄 : 非集計行動モデルの移転可能性に関する研 究の経緯, 東京工業大学土木工学科研究報告, No. 32, 1984.

37）森地 茂·屋井鉄雄・田村 亨: 非集計交通手段選択 モデルの地域間移転可能性，土木学会論文集，第 359 号 / IV -3, pp. 107 115, 1985.

38）森地 茂: 非集計行動モデルによる予測, 土木学会, 土木計画学講習会テキスト 15, pp. 121-147, 1984.

39）森地 茂·屋井鉄雄 - 藤井 卓 - 竹内研一：買回品 の買物行動における商業地選択分析, 土木学会, 土木 計画学研究, 論文集 I, pp. 27-34, 1984.

40) Morichi, S., Ishida, H. and T. Yai. : Comparison of
Various Utility Functions for Behavioural Travel Demand Model, World Conference on Transport Research 83, Vol. 1, pp. 159-173, 1983.

41）森地 茂・屋井鉄雄・田村 亨: 非集計行動モデルに よる OD 交通量推計方法, 土木学会, 土木計画学研究, 論文集 2 , pp. 45-52， 1985.

42）宮城俊彦・加藤 晃: ランダム効用理論を基礎とした 交通統合モデル, 土木学会, 土木計画学研究, 論文集 I, pp. 99-106, 1984.

43）森地 茂・屋井鉄雄・平井節生 : 非集計行動モデルに よる都市圈 $\mathrm{OD}$ 表の推計, 第 40 回土木学会年講, $\mathrm{pp}$. $399-400,1985$.

44）屋井鉄雄・森地 茂: 交通量データを用いた非集計行 動モデルの改良方法, 第 40 回土木学会年講, pp. 397398, 1985.

(昭和 59 年度土木学会論文奖励賞受賞) 